\title{
Kalina Wojciechowska, Mariusz Rosik, Mq̨drość zstępujq̨ca z góry. Komentarz strukturalny do Listu św. Jakuba, Wydawnictwo Naukowe Chrześcijańskiej Akademii Teologicznej, Warszawa 2018, 300 s.
}

\author{
Dominik Tomczyk \\ Chrześcijańska Akademia Teologiczna \\ dt@dominiktomczyk.com (D) https://orcid.org/0000-0003-0023-9153
}

Książka, którą trzymam w ręce, zwróciła moją uwagę na trzy elementy. Pierwszy to słowo „mądrość”, a raczej wyrażenie „mądrość zstępująca z góry”. Drugi to „komentarz strukturalny”. A trzeci to dwa nazwiska autorów, którzy pochodzą z różnych tradycji teologicznych.

Kalina Wojciechowska, luteranka, biblistka, oraz ks. Mariusz Rosik, katolik, biblista. Nie jest to bez znaczenia, jeśli weźmiemy pod uwagę wielowiekowe „przepychanki” teologiczne dotyczące wiary i uczynków, które w szczególny sposób zogniskowały wzajemne antagonizmy wokół Listu św. Jakuba.

Marcin Luter mocno zaakcentował sola fide, sola gratia i sola scriptura, które nawiązywały do Pawłowej zasady „tylko wiara”. Autor Listu Jakuba podkreślił przeciwstawną zasadę „wiary i uczynków”. List ten komentowany był historycznie w odniesieniu do teologii Pawła. Współcześnie „zyskuje coraz większą autonomię" (s. 28) i to stało się punktem wyjścia dla autorów komentarza.

Określenie „komentarz strukturalny” być może brzmi dla „niewtajemniczonych" trochę obco. Jest to metoda badawcza języka, która weszła na dobre do biblistyki. Jej podstawy zawarte zostały w książce szwajcarskiego językoznawcy Ferdinanda de Saussure’a Cours de linguistique generale ${ }^{1}$. „W swojej najprostszej postaci strukturalizm głosi, że natura pojedynczego składnika w danej sytuacji nie ma znaczenia sama w sobie, bowiem w rzeczywistości określają ją związki ze wszystkimi innymi elementami składającymi się na tę sytuację. Krótko mówiąc, pełnego znaczenia jakiejś rzeczy czy przeżycia

1 Éditions Payot \& Rivages, Paris 1916; Kurs językoznastwa ogólnego, tł. K. Kasprzyk, PWN, Warszawa 1961. 
nie można zrozumieć, jeśli nie zostanie ono włączone w strukturę, której część stanowi”2.

Ułożenie planu Listu Jakuba nie jest rzeczą łatwą. W tym kontekście oboje biblistów spojrzało na niego w odmienny sposób niż dotychczasowi komentatorzy. Nie mamy tutaj bowiem do czynienia z komentarzem linearnym rozdział po rozdziale i wiersz po wierszu oraz z ich egzegezą, do czego z pewnością jesteśmy przyzwyczajeni. Dla przykładu wspomniany w pracy Martin Dibelius (s. 27-28) w swoim linearnym komentarzu dokonał podziału Listu na 3 części: zbiory (o pokusach, o słuchaniu i czynieniu: 1, 2-27), traktaty (o postrzeganiu osoby, o wierze i uczynkach, o języku: 2, 1-3, 12) i grupy (przeciw kłótni, przeciwko światowym kupcom i bogatym, inne tematy: $3,13-5,20)^{3}$.

Autorzy komentarza omówili kilka propozycji strukturalnego podziału tekstu (Amphoux, Kozyra, Taylor, Davids, Baasland, Cargal). Odwracając koncepcję układu zaproponowanego przez Mongstad-Kvammena polscy bibliści tekst Jk 3, 13-18 uznali za element porządkujący strukturę Listu (s. 71, 296). Mądrość stała się „zasadniczym tematem całego listu”, gdzie „wiara przestaje być jedynie deklaracją, a staje się czynem” (s. 72).

Indeks cech i przejawów mądrości, które odnajdujemy w tekście Jk 3, 17 stał się podstawą omawianej publikacji. Czytamy tam: „Mądrość zaś [zstępująca] z góry jest przede wszystkim czysta, dalej, skłonna do zgody, ustępliwa, posłuszna, pełna miłosierdzia i dobrych owoców, wolna od względów ludzkich i obłudy”.

Omawiana praca - pomijając wstęp (s. 25-31) oraz zakończenie (s. 295-296) składa się z dwóch głównych części: wprowadzenia (s. 35-109) i komentarza strukturalnego (s. 113-292).

We wprowadzeniu autorzy omawiają świadectwa tekstowe i kwestię kanoniczności Listu Jakuba (s. 35-42), jego autora (s. 43-55), czas powstania (s. 56-59), słownictwo, styl i strukturę całego Listu (s. 60-72), jego gatunek literacki (s. 72-89) oraz nadawcę i adresatów (s. 89-109).

Pomimo że greckie бọía występuje w omawianym Liście tylko 4 razy (Jk 1, 5; 3, 13.15.17; 3, 17), to klucz sapiencjalny stanowi modus vivendi omawianego komentarza. Nie oznacza to, że nie został skomentowany cały List Jakuba. „Perykopy zgrupowano bowiem w poszczególnych częściach

2 T. Hawkes, Strukturalizm i semiotyka, tł. I. Sierdzaki, PWN, Warszawa 1988, s. 16.

3 Zob. M. Dibelius, Der Brief des Jakobus, Vandenhoeck \& Ruprecht, wyd. 12, Göttingen 1984. 
komentarza w zależności od tego, który aspekt chrześcijańskiej mądrości jest w nich omawiany" (s. 296).

Dla autorów kryterium semantyczne, czasem pokrywające się z leksykalnym, stało się punktem wyjścia komentarza. W jego głównej części w 9 podrozdziałach opatrzonych określeniem „mądrość” omawiają oni treść Listu Jakuba. Wychodząc od treści tekstu Jk 3, 17, analizie została poddana

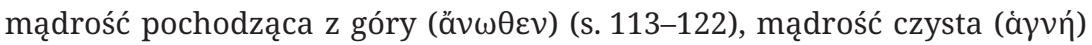

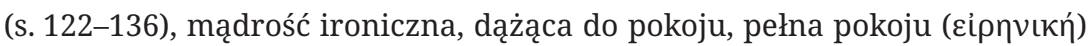

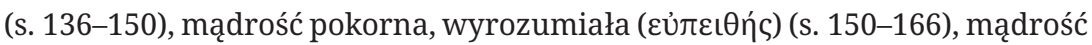

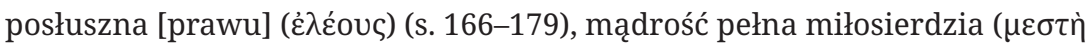

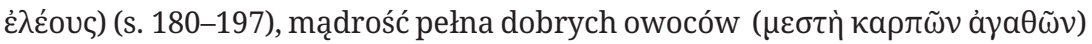

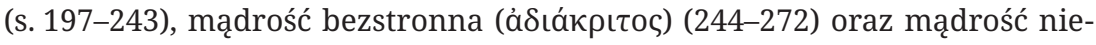

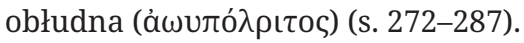

Wszystkie omawiane sigla Listu św. Jakuba zostały zestawione w tabeli na s. 113, czyli na pierwszej stronie komentarza strukturalnego. Z reguły przyzwyczajeni jesteśmy do indeksu tekstów biblijnych na końcu publikacji. Patrząc od strony czytelnika, tego brakuje. Podobnie jak indeksu słów greckich, który byłby bardzo przydatny dla szybkiego odnalezienia interesującego nas słowa. Opracowanie skorowidza rzeczowego byłoby także dużą pomocą przy korzystaniu z dzieła. Warto o tym pamiętać przy kolejnym wydaniu komentarza.

Czytelnik zwróci z pewnością uwagę na brak komentarza do Jk 1, 1. Z pewnością nie jest to wymagane, ponieważ kwestię autora Listu oraz jego nadawcę i adresatów omówiono dość szczegółowo we wstępie. Inny tekst Jk 3, 13 został omówiony w podsumowaniu.

Podsumowując omawianą publikację, należy podkreślić jej dwie główne cechy. Po pierwsze, zastosowany klucz interpretacyjny, w ramach którego zrezygnowano świadomie z komentarza linearnego na korzyść zgrupowania tekstów wokół przymiotów mądrości. Po drugie, ekumeniczny charakter dzieła, które winno być traktowane jako impuls „na rzecz wzrostu jedności” i znak „nadziei na przekroczenie podziałów” pomiędzy katolicyzmem i luteranizmem (s. 296). „Przekroczenie podziałów” stało się bardzo namacalne choćby w odejściu od wyraźnego podkreślania denominacji przy nazwiskach współczesnych biblistów, jak to było czynione jeszcze kilkanaście lat temu.

Ekumenizm dzieła przejawia się również w tym, że każda ze stron mogła zaakcentować te prawdy, które są żywe w tradycji katolickiej i luterańskiej. Śmiało można powiedzieć, że dla szeroko rozumianego protestantyzmu, który 
ponad 500 lat temu zapoczątkował Marcin Luter, prezentowany komentarz stanowić powinien jedną z podstawowych lektur do głębszego zrozumienia istoty Jakubowego nauczania o wierze i uczynkach oraz ich wzajemnej relacji.

Jeżeli poszukujemy w omawianej monografii klasycznego komentarza do Listu św. Jakuba, z pewnością możemy być nieco zawiedzeni. Jeżeli natomiast poszukujemy odkrycia zawartych w Liście teologicznych treści, będziemy pozytywnie zaskoczeni bogactwem tego, co autorzy przygotowali. Zastawili oni bowiem bogaty „stół Słowa Bożego”, przybliżając nam głębię treści niełatwych Jakubowych tekstów. Lingwistyczne piękno grecki Listu Jakuba możemy podziwiać w nowoczesnym tłumaczeniu, którego celem jest jak najwierniejsze oddanie Jakubowego przesłania poprzez ukazanie wieloznaczności używanych słów przez autora Listu (s. 30). W poszukiwaniu rdzenia biblijnego tekstu autorzy wykorzystali całą paletę współczesnego literaturoznawstwa.

Nie dziwić nas powinien klucz „mądrości”, według którego dzieło Jakuba zostało ustrukturyzowane i skomentowane. „Mądrość bowiem jest ruchliwsza od wszelkiego ruchu i przez wszystko przechodzi, i przenika dzięki swej czystości. Jest bowiem tchnieniem mocy Bożej i przeczystym wpływem chwały Wszechmocnego" (Mdr 7, 24-25).

Praca Kaliny Wojciechowskiej oraz ks. Mariusza Rosika jest wyjątkowa nie tylko w obszarze polskiej biblistyki, ale zdecydowanie wykracza poza jej ramy. Można mieć nadzieję, że tak owocna współpraca nad odkrywaniem tekstów Jakuba przełoży się na inne wspólne prace obu autorów w przyszłości. 